\title{
Hosszú távú túlélés és iniciális ritmus közötti összefüggés hirtelen szívhalál esetén
}

\author{
Szigethi Tímea, Pileczky Dávid, Pap Zsófia, Fekete-Győr Alexandra, \\ Kovács Enikő, Heltai Krisztina, Molnár Levente, Ruzsa Zoltán, Bárczi György, \\ Gellér László, Becker Dávid, Merkely Béla, Zima Endre
}

\author{
Semmelweis Egyetem, Városmajori Szív- és Érgyógyászati Klinika, Budapest \\ Levelezési cím: Dr.Zima Endre, E-mail: zima.endre@gmail.com
}

\begin{abstract}
Bevezetés: A hirtelen szívhalál (HSZH) vezető halálozási okként szerepel a fejlődő ipari országokban, amelynek hátterében leggyakrabban malignus ritmuszavarok állnak. Ezeket sokkolandó (kamrafibrilláció, kamrai tachycardia), illetve nem sokkolandó (asystolia, elektromechanikus disszociáció) formákra osztjuk. Célkitűzés: Vizsgálatunk célja volt összehasonlítani a hosszú távú túlélést HSZH esetén, sokkolandó, illetve nem sokkolandó ritmusú betegek esetében. Anyag és módszer: Retrospektív tanulmányunkban a SE VSZÉK-án 2008 és 2011 között kezelt, 116 hirtelen szívhalált elszenvedett, konszekutív beteg adatait vetettük össze. Hirtelen szívhalált követően az iniciálisan észlelt ritmus szerint két csoportba soroltuk őket, és összehasonlítottuk a túlélési arányokat kórhazi távozáskor, egy hónapot, illetve három hónapot követően. Statisztika analizist t-próba, $\chi^{2}$-próba és nem parametrikus (Mann-Whitney-Wilcoxon) próba segítségével végeztünk. Az iniciálisan tisztázatlan ritmussal rendelkező betegek kizárásra kerültek. Eredmények: A vizsgált populáció $67 \%$-a rendelkezett iniciálisan sokkolandó ritmussal. Szignifikánsan magasabb számban távoztak a kórházból a sokkolandó ritmusú csoport tagjai $\quad 54 \%$ vs. $16 \%, p=0,0002)$. Az első és a harmadik hónapot túlélt betegek aránya sziginifikánsan magasabb volt a sokkolandó ritmusú csoportban mindkét vizsgált időpontban $60 \%$ vs. $24 \%, p=0,0001$, illetve $49 \%$ vs. $16 \%, p=0,0004$. Következtetés: Az általunk vizsgált esetekben, hirtelen szívhalált követően lényegesen jobb prognózissal rendelkeztek az iniciálisan sokkolandó ritmusú betegek, mint a nem sokkolandó ritmusú társaik, amely megegyezést mutat az irodalommal.
\end{abstract}

Kulcsszavak: hirtelen szívhalál, túlélés, iniciális ritmus, defibrilláció, reanimáció

Relationship between survival and initial rhythm after cardiac arrest

Background: The sudden cardiac death (SCD) is one of the main purposes of death in the developing countries. The most common causes of SCD are malignant arrhythmias. That could be devided into two major groups by sort: shockable (ventricular fibrillation, ventricular tachycardia) and non-shockable rhythms (asystole, pulseless electrical activity). Aim and Methods: The aim of this study was to analize the long-term survival after SCD due to initial rhythm. The data were collected retrospectively from Semmelweis University Heart and Vascular Center between 2008 and 2011. We analized the data of 116 consecutive patient. Patients were devided to initial shockable (SR) and non-shockable rhythm (NSR) groups, and we compared the survival rates at hospital discharge, and after 1 and 3 months. Patients detected with unclear data of initial rhythm were excluded. Statistical analysis was performed with non-parametric tests, $\chi^{2}$ test and $t$ test. Results: $67 \%$ of patients have got initially shockable rhythm. Patients with SR had a higher hospital discharge rate than those with NSR ( $54 \%$ vs. $16 \%, p=0.0002)$. The 1-month and 3-months survival rates were significantly higher in the SR group, than in the NSR in both cases, $60 \%$ vs. $24 \%, p=0.0001$, and $49 \%$ vs. $16 \%, p=0.0004$. Conclusion: In our experience, after sudden cardiac death patients with initial shockable rhythm have higher chance of long-term survival, which contributes with international data.

Keywords: cardiac arrest, survival, initial rhythm, defibrillation, resustitation 


\section{Bevezetés}

A természetes halál hátterében leggyakrabban kardiovaszkuláris ok áll. Ezek között a hirtelen szívhalálnak kiemelkedő szerep jut, mivel a szíveredetű elhalálozások jelentős része váratlan (1). Bár fontos elörelépések történtek az elmúlt 30 évben a kardiopulmonalis resuscitatio, illetve az utókezelések terén, a túlélési mutatók még mindig nem kedvezőek.

Hirtelen szívhalálnak (HSZH) nevezzük azt a tünetegyüttest, ahol a természetes, váratlan halál a tünetek megjelenését követö egy órán belül beáll $(2,3)$. Körülbelül 17 millióan halnak meg évente kardiovaszkuláris megbetegedésekben. A HSZH incidenciája az irodalmi közlések alapján igen széles heterogén tartományban $15-50 \%$ között mozog, adatforrások, földrajzi és demográfiai mutatóktól függően. Kialakulása magasabb a fejlődő ipari országokban $(1,3,5,16)$.

A HSZH előfordulását növeli különböző rizikófaktorok jelenléte. Az életkor előrehaladtával száma drasztikusan nő, gyakoribb 60 év felett. A nembeli eloszlást tekintve, 2-3-szor gyakrabban fordul elő férfiak esetében (5). Rizikófaktorai megegyeznek a koronáriabetegség rizikófaktoraival, úgymint magas vérzsírértékek, magas vérnyomás, dohányzás, fizikális inaktivitás, obesitas, cukorbetegség, emelkedett szérum CRP, túlzott alkoholfogyasztás, illetve pozitív családi anamnézis koronáriabetegségre és miokardiális infarktusra nézve.

Etiológiáját tekintve életkori különbségek figyelhetök meg. Fiatalkorban a HSZH hátterében leginkább genetikai-, illetve veleszületett organikus okokból kialakuló ritmuszavarok (channelopathia, hypertrophiás cardiomyopathia, kongenitális hosszú QT-szindróma, aritmogén jobbkamra-diszplázia, kongenitális koronária-anomáliák, mitralis billentyü-prolapszus vagy Brugada-szindróma), myocarditis és gyógyszerek vagy egyéb szerek által kiváltott ritmuszavarok állnak (1, 4). Az idősebb korosztályban a krónikus degeneratív megbetegedések dominálnak, úgymint koszorúér-betegség, szívelégtelenség, szívbillentyü-betegség (3). A HSZH leggyakrabban ismert szívbetegségben szenvedőknél alakul ki, de sok esetben lehet a kardiovaszkuláris megbetegedés első jele.

A HSZH kialakulásában ugyanakkor fontos szerep tulajdonítható különböző triggereknek és modifikáló faktoroknak is, mint például az elektrolit-háztartás zavarainak (hypokalaemia, hypomagnezaemia), antiaritmiás gyógyszerek proaritmiás hatásának, autonóm idegrendszer aktivációjának vagy pszichoszociális faktoroknak (4).

A hirtelen szívhalál hátterében észlelt ritmusokat reanimatológiai szempontból két csoportba sorolhatjuk, sokkolandó (kamrai tachycardia, kamrafibrilláció) és nem sokkolandó (asystolia, pulzus nélküli elektromos aktivitás), aszerint, hogy megszüntethetőek-e vagy sem defibrillációval/kardioverzióval.

A hirtelen szívhalál gyors, szakszerủ beavatkozást igényel, mivel a még rövid ideig fennálló hipoperfúzió is visszafordíthatatlan agy- és szívizom, illetve célszerv- károsodást okozhat. Fontos a keringés fenntartása mellett az akut, reverzibilis okok gyors felismerése és azonnali kezelése, a strukturális szívbetegség felismerése, ingerületvezetési zavarok felderítése $(3,5)$.

A túlélést befolyásoló tényezők közül kiemelendők az újraélesztés körülményei: a beteg életkora, az iniciális ritmus, az alapbetegségek, a keringés-összeomlás időtartama (keringés nélküli állapot időtartama), a kardiopulmonalis resuscitatio (CPR) időtartama, illetve a postresuscitatiós ellátás minősége (6). A kezelés rövid távú céljai között szerepelnie kell a stabil hemodinamikai állapot és gázcsere fenntartásának, az esetleges elektrolit-háztartási zavarok korrigálásának, valamint szükség esetén a terápiás hypothermia (THT) inicializálásának (7).

A HSZH-t elszenvedett betegek elhalálozásának oka elsősorban neurogén károsodás, kardiogén károsodás vagy többszervi elégtelenség. Elöbbi csökkenthető THT alkalmazásával, illetve normothermia fenntartásával. Már a 2000-es évek elején kimutatták, hogy a 12-24 óráig fenntartott $32-34{ }^{\circ} \mathrm{C}$ THT növelte a túlélési arányt és pozitívan befolyásolja a neurológiai státuszt, mindkét iniciális ritmuscsoport esetében (7).

Hirtelen szívhalál esetén az iniciális ritmus függvényében változik az akut ellátás. Míg a sokkolandó ritmusok esetén akár egy DC-sokkal gyorsan megszüntethető az életet veszélyeztető ritmuszavar, addig a nem sokkolandó ritmusok esetén komplexebb beavatkozásokra van szükség. A nem sokkolandó ritmusok esetén az alap- és emeltszintủ újraélesztés mellett párhuzamosan az esetlegesen fennálló súlyosbító reverzibilis oki tényezők felfedésére és megoldására is törekedni kell, úgymint: tamponád, tenziós pneumothorax, toxinhatások, trombembólia, hyper- vagy hypokalaemia, hypovolaemia, hypothermia, hypoxia $(4 \mathrm{H}, 4 \mathrm{~T})(6)$.

\section{Betegek és módszerek}

Tudományos munkánk során retrospektív vizsgálatot végeztünk a Semmelweis Egyetem Városmajori Szívés Érgyógyászati Klinikán, 2008-2011 között az intézményben kezelt, hirtelen szívhalált szenvedett 200 konszekutív beteg adatait feldolgozva. A vizsgálat során összesen 116 beteg adatait elemeztük. Kizárásra kerültek a bizonytalan iniciális ritmusú esetek, ahol nem volt dokumentáció az első ritmusról, a bradycardiák, nem dokumentált, de automata defibrillátor (AED) elemzés alapján végzett laikus $C P R$, illetve azok az esetek ahol a sokkolandó, nem sokkolandó ritmusok gyakran váltogatták egymást. Adatforrásul szolgáltak a MedSol, BedMap, kórlapok, lázlapok, OMSZ jelentőlapok.

A vizsgált populációt két nagy csoportra osztottuk az iniciálisan észlelt ritmus szerint: sokkolandó (SR), illetve nem sokkolandó (NSR) ritmusú betegek csoportjára. Az esetek között egyaránt előfordult kórházon kívül (OHCA) és kórházon belül (IHCA) kialakult hirtelen szívhalál. 
Vizsgálatunk célja volt a túlélést befolyásoló alaptényezők kiértékelése és összehasonlítani a hosszú távú túlélést a két csoport esetében. Megfigyeltük a túlélési arányokat kórházi távozáskor, 1 hónapot és 3 hónapot követően. Statisztikai analízist GraphPad Instat 3 programmal, nem parametrikus próbák (Mann-WhitneyWilcoxon), $\chi^{2}$-próba és t-próba segítségével végeztünk.

\section{Eredmények}

Vizsgálatunk során összesen 116 beteg adatait dolgoztuk fel, közülük 78-an rendelkeztek sokkolandó, 38-an pedig nem sokkolandó ( $68 \%$ vs. $32 \%$ ) iniciális ritmussal. Demográfiai adatok és alapbetegségek szempontjából nem volt eltérés a két csoport között. Úgy a sokkolandó, mint a nem sokkolandó ritmusú csoport esetén, az életkor tekintetében az irodalmi adatokkal korreláló eredményeket kaptuk. Mindkét csoportban szignifikánsan magasabb volt a 65 év fölöttiek száma ( $60 \%$ vs. $74 \%$ ), illetve a nembeli eloszlás is az elvártak szerint alakult, a férfi/nő arány 54/27 vs. 21/17, összességében 75/41. A kardiovaszkuláris rizikófaktorok közül kiértékeltük a hipertónia, hyperlipidaemia, cukorbetegség továbbá az akut szívizominfarktus előfordulását a két csoport esetében. Nem volt szignifikáns eltérés az SR- és az NSR-csoportok között egyik esetben sem (1. táblázat). A reanimációs körülmények alakulását a vizsgált csoportok esetében a 2. táblázatban foglaltuk össze.

A két csoport között egyik esetben sem volt szignifikáns különbség a reanimációs idők tekintetében, bár a spontán keringés visszatéréséig tendenciózusan több idő telt el a nem sokkolandó ritmusú betegek esetében.

Keringés-összeomlás és újraélesztés alatt fontos a keringés megfelelő szinten tartása, a középnyomás optimális célértéken való tartása, 95-100 Hgmm (6). A hemodinamikai stabilitás érdekében gyakran szükség van gyógyszeres (elsősorban katekolamin) keringéstámogatásra. Az általunk vizsgált csoportok esetén az esetek 2/3-ában nem volt szükség gyógyszeres keringéstámogatásra $(65,38 \%$ vs. $68,42 \%)$, de ha mégis akkor nem volt szignifikáns különbség a két csoport között monoterápia, illetve kombinált terápiát illetően $(p=0,955$, illetve $p=0,654)$.

Eredményeink azt mutatták, hogy már a kórházi túlélés is kiemelkedően magasabb volt a sokkolandó ritmusú csoportban, mint a nem sokkolandóban ( $54 \%$ vs. $16 \%$,

1. TÁBLÁZAT. Társbetegségek előfordulása

\begin{tabular}{|l|l|l|l|}
\hline Társbetegségek & SR & NSR & p \\
\hline Hipertónia & $57(73 \%)$ & $29(76,31 \%)$ & 0,696 \\
\hline Hyperlipidaemia & $26(33,33 \%)$ & $14(36,84 \%)$ & 0,712 \\
\hline Cukorbetegség & $20(25,64 \%)$ & $13(34,21 \%)$ & 0,269 \\
\hline Korábbi AMI & $18(23 \%)$ & $7(18,42 \%)$ & 0,571 \\
\hline
\end{tabular}

\begin{tabular}{|l|c|c|c|}
\hline \multicolumn{2}{|c|}{ 2. TÁBLÁZAT. Reanimációs körülmények } & \\
\hline $\begin{array}{l}\text { Keringésleálláskor } \\
\text { szemtanú jelenléte }\end{array}$ & $61(78 \%)$ & $29(76 \%)$ & 0,487 \\
\hline BLS & $54(69 \%)$ & $25(66 \%)$ & 0,518 \\
\hline $\begin{array}{l}\text { Kollapszus-ALS-ig eltelt } \\
\text { átlagidő (perc) }\end{array}$ & 4 & 6 & 0,096 \\
\hline \begin{tabular}{l} 
ROSC-ig eltelt idő (perc) \\
\hline
\end{tabular} & 27 & 31 & 0,061 \\
\hline
\end{tabular}

\section{TÁBLÁZAT. Gyógyszeres keringéstámogatás}

\begin{tabular}{|l|c|c|c|}
\hline Katekolamin & SR & NSR & p \\
\hline Nem kapott & $51(65 \%)$ & $26(68 \%)$ & 0,972 \\
\hline Monoterápia & $12(15 \%)$ & $6(16 \%)$ & 0,955 \\
\hline Kombinált terápia & $15(19 \%)$ & $6(16 \%)$ & 0,654 \\
\hline
\end{tabular}

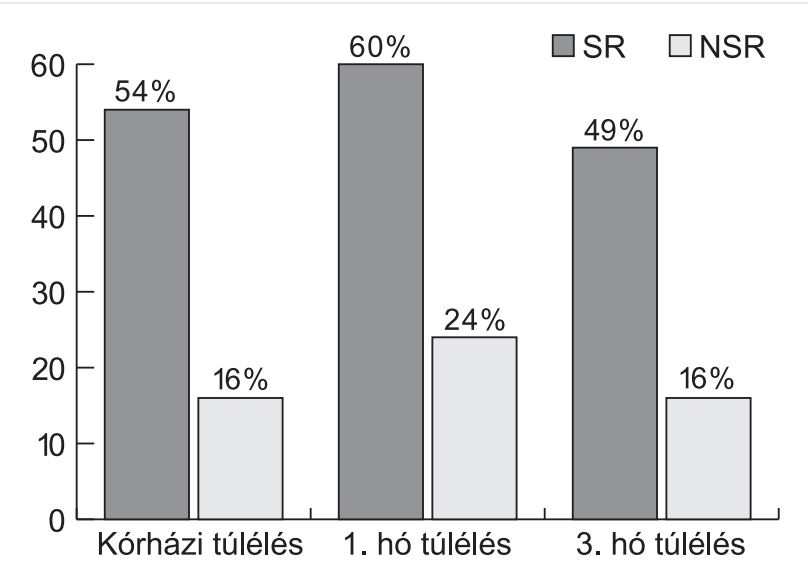

1. ÁBRA. Túlélési arányok a vizsgált időpontokban

$\mathrm{p}=0,0002)$. Hasonló eredményeket kaptunk az 1 , illetve 3 hónapos túlélés vizsgálata esetén is. Mindkét időpontban lényegesen magasabb volt a túlélési arány az iniciálisan sokkolandó ritmusú betegek csoportjában ( $60 \%$ vs. $24 \%, p=0,0001$, és $49 \%$ vs. $16 \%, p=0,0004$ ) (1. ábra).

\section{Megbeszélés}

Annak ellenére, hogy az elmúlt évtizedben számos ponton továbbfejlesztésen és egyszerüsítésen esett át a resuscitatiós protokoll, illetve egyre több helyen válik elérhetővé az automata defibrillátor használata és a korai defibrilláció, a hirtelen szívhalál prognózisa és hoszszú távú túlélési mutatói nem változtak számottevően (4). Bár irodalmi adatok azt mutatják, hogy HSZH esetén növekvő tendenciát mutat a nem sokkolandó iniciális ritmus (8), jelen esetben mégis magasabb volt az iniciálisan sokkolandó ritmussal rendelkező betegek száma. Tanulmányunk is mutatja, hogy a kedvezőtlen eredmé- 
nyek nem sokkolandó iniciális ritmus esetén fordulnak elő gyakrabban, úgy a prognózis, mint a neurológiai státuszt illetően, hasonló eredményekkel találkoztunk több helyen is az irodalomban $(9,10,11)$. Viszont elmondhatjuk, hogy léteznek túlélést pozitívan befolyásoló tényezők is, amelyek a következők: fiatal életkor, sokkolandó iniciális ritmus, női nem, ROSC-ig eltelt idő $(11,12)$.

Saját 116 tagú, társbetegségek tekintetében homogén, betegcsoporton végzett tanulmányunk is egyértelmüen következtet arra, hogy a fent említett túlélést javító tényezők közül kiemelkedő szerep jut az iniciális ritmusnak, hiszen a sokkolandó ritmusú csoport tagjai szignifikánsan magasabb rövid- és hosszú távú túlélési rátát mutattak. Hasonló eredményekről számoltak be Tatsuma Fukuda és munkatársai, illetve Nadine és munkatársai, esetükben is iniciálisan sokkolandó ritmus esetén magasabb volt a kórházi túlélési arány, sőt jobb volt a későbbi neurológiai státusz is $(13,14)$. Valamint a közelmúltban kiadott brazil prospektív vizsgálat is, amely szerint az iniciálisan észlelt ritmus a legjobb prediktor a túlélésre nézve, és a sokkolandó ritmusok rendelkeznek a legjobb hosszú távú túlélési prognózissal (11). A nemek és a HSZH-t követő túlélés alakulását vizsgáló metaanalízis is azt mutatta, hogy az iniciálisan észlelt sokkolandó ritmus pozitív prognosztikai faktornak számít (15).

Szintén bizonyítja a sokkolandó ritmus pozitív prognosztikai hatását Yoshizaku Goto és munkatársai által végzett tanulmány, amelynek eredménye szerint az iniciálisan nem sokkolandó ritmussal rendelkező betegek esetében, ahol a ritmus átváltott a CPR alatt sokkolandó ritmussá kedvezőbb 1 hónapos túlélési arányt és neurológiai státuszt mutattak, mint a nem sokkolandó, nem konvertált társaik (10).

Ezzel ellentétes eredményt mutatott ki Thomas és munkacsoportja, akik nem véltek felfedezni különbséget túlélést illetően NSR-ről SR-re konvertált betegek, illetve NSR-rel rendelkező betegek esetében, véleményük szerint, míg egyes NSR etiológiára pozitívan hat a ritmuskonverzió, addig másokat negatívan befolyásol (8). A 2010-2015-ig érvényben lévő Európai Resuscitatiós Társaság irányelveiben meghatározott, a túlélést befolyásoló tényezők közül kiemelkedőek az újraélesztés közvetlen körülményei. Közülük is fontos szerep jut a keringés-összeomlás pillanatától az újraélesztésig eltelt időnek és az újraélesztés időtartamának, mivel a no-flow, illetve a low-flow időtartamok kedvezőtlenek a túlélésre nézve a következményes hipoperfúzió és irreverzibilis szervkárosodás miatt (6). Annak ellenére, hogy számos tanulmányban $(10,14)$ az ROSC-ig eltelt idő, illetve a szemtanú által idejében megkezdett alapszintű újraélesztés pozitívan befolyásolta a túlélést esetünkben ez nem volt megfigyelhető, nem volt szignifikáns különbség e tekintetben a két csoport között. Más tanulmányok szerint viszont a laikus által végzett BLS csak sokkolandó ritmus esetén rendelkezik jelentős túlélést befolyásoló értékkel (8).
Esetünkben nem sokkolandó ritmus esetén a betegek mindössze $16 \%$-a hagyta el a kórházat, hasonló vagy talán még kedvezőtlenebb eredményt mutattak ki $E$. Andrew és munkatársai is, esetükben NSR esetén a kórházi túlélés mindössze $7 \%$ volt, pozitív változás hiányára is utalva ezzel az elmúlt tíz évre nézve és az NSR negatív hatására a hosszú távú túlélést illetően (9).

Összegzésként elmondható, hogy HSZH esetén az iniciálisan észlelt ritmus nagymértékben enged következtetni a hosszú távú túlélésre. Eredményeink alapján elmondható, hogy az iniciálisan sokkolandó ritmus pozitív prognosztikai faktorként szerepel hirtelen szívhalál esetén. Azonban nem feledkezhetünk meg egyéb fontos befolyásoló tényezőkről sem, úgymint nem, életkor, ALS-ig és ROSC-ig eltelt idő vagy szemtanú jelenléte és közbelépése.

\section{Irodalom}

1. Loscalzo J. Harrison's Cardiovascular Medicine, derived from Harrison's Principles of Internal Medicine. 17th Edition, US: The McGrow-Hill Companies, 2010, 311-320.

2. Préda I, Czuriga I, Édes I, et al. Hirtelen szívhalál, In: Merkely B, Róka A, Kardiológia Alapok és irányelvek. $1^{\text {st }}$ ed. Budapest: Medicina Könyvkiadó; 2010. pp. 625-635.

3. Priori SG, Blomström-Lundgvist C, Mozzanti A, et al. ESC Guidelines for the management of patients with ventricular arrhythmias and the prevention of sudden cardiac death. European Heart Journal 2015, 36: 2793-2867. https://doi.org/10.1093/eurheartj/ehv316

4. Merkely B, Róka A. Beültethető eszközök a kamrai tachyarrhythmiák kezelésére. Cardiologia Hungarica 2008; 38: C9-13.

5. Podrid PhJ. Overview of sudden cardiac arrest and sudden cardiac death, UpTodate 2014

6. Nolan JP, Soar J, Zideman DA, et al. European Resustitation Council Guidelines for Resuscitation 2010 Section 1. Executive Summary. Resuscitation 2010; 81: 1219-1276.

\section{https://doi.org/10.1016/j.resuscitation.2010.08.021}

7. Rittemberg JC, et al. Post-cardiac arrest management in adults. UpToDate 2014

8. Nolan JP. Optimizing outcome after cardiac arrest. Current Opinion on Critical Care 2011; 17: 520-526.

\section{https://doi.org/10.1097/MCC.0b013e328349bc57}

9. Andrew $\mathrm{E}$, Nehme Z, Lijovic M, et al. Outcomes following out-of-hospital cardiac arrest with an initial cardiac rhythm of asystole or pulsless electrical activity in Victoria. Australia, Resustitation 2014; 85: 1633-1639

https://doi.org/10.1016/j.resuscitation.2014.07.015

10. Cueni-Villoz N, Devigili A, Delodder A, et al. Increased blood glucose variability during therapeutic hypothermia and outcome after cardiac arrest. Critical Care Medicine 2011; 39: 2225-2231. https://doi.org/10.1097/CCM.0b013e31822572c9

11. Vancini-Campanharo CR, Vancini RL, Barbosa de Lira CA, et al. Cohort study on the factors associated with survival post cardiac arrest. Sao Paulo Medical Journal 2015; 133(6): 495-501. https://doi.org/10.1590/1516-3180.2015.00472607

12. Kitamura T, Iwami T, Kawamura $\mathrm{T}$, et al. Nationwide improvements in survival from out-of-hospital cardiac arrest in Japain. Circulation 2012; 126: 2834-2843

https://doi.org/10.1161/CIRCULATIONAHA.112.109496

13. Thomas A, Newgard C, Fu R, et al. Survival in out-of-hospital cardiac arrests with initial asystole or pulseless electrical activity and subsequent shockable rhythms. Resuscitation 2013; 84(9): 1261-1266. https://doi.org/10.1016/j.resuscitation.2013.02.016

14. Goto Y, Maeda T, Nakatsu-Goto Y. Prognostic implications of convertion from nonshockable rhythms in out-of-hospital cardiac arrest. Critical Care 2014; 18: 528. 
https://doi.org/10.1186/s13054-014-0528-7

15. Bougouin W, Mustafic H, Marijon E, et al. Gender and survival afer sudden cardiac arrest: A systematic review and meta-analysis.

Resuscitation 2015; 94: 55-60.

https://doi.org/10.1016/j.resuscitation.2015.06.018
16. Tubaro M, Vranckx P, Price S, Vrints $\mathrm{CH}$. The ESC Textbook of Intensive and Acute Cardiovascular Care (The European Society of Cardiology Textbooks) 2nd Edition, United Kingdom (UK): Oxford University; 2015

https://doi.org/10.1093/med/9780199687039.001.0001 